https://doi.org/10.52449/1857-4114.2020.36-2.12

CZU: 37.015.3: 373.037.1-053.2

\title{
MOTIVATION FOR ATTENDING PHYSICAL EDUCATION LESSONS BY 14-15 YEAR- OLD STUDENTS
}

\author{
Delipovici Irina ${ }^{\boldsymbol{1}}$, ORCID: 0000-0002-1409-9318 \\ ${ }^{1}$ State University of Physical Education and Sport, Chisinau, Republic of Moldova
}

\begin{abstract}
The level of motor training of students is not a stable index over a period of time. It degrades if the physical activity of the individual is reduced or the practice of physical exercises does not have a systematic character. This process takes place, for example, at the beginning of the school year, for the students who did not play sports during the holidays. For this reason, one of the tasks of physical school education is to train - educate students and form the stable motivation for practicing physical exercises throughout the year, the formation of the skills and abilities to organize the physical activity independently, based on the consideration that, over time, the motivation for practicing physical exercises will decrease. But the motivation is closely related to the gratification of what students have in relation to the physical education lessons. It has been established that the gratification of the physical education lessons is tested by $60 \%$ of the students in the primary classes, while in the secondary classes only 30\%. The degree of gratification from the physical education lessons is an important component of the children's attitude towards this discipline. Motivated physical activity is one of the most important characteristics of modern physical culture.
\end{abstract}

Keywords: motivation, gratification, physical education lessons, physical exercises, teenagers, physical education teachers.

Actuality. At the present stage, the change of the attitude of the society towards the physical culture for the better still does not find its reflection neither in the state documents, nor in the real behaviour of the students, who are not attracted by the physical activity in the sports sections, but neither are not willing to give the movement some of their free time [1]. On the contrary, the students seek different pretexts to avoid the lessons, and parents are concerned about obtaining the certificates that would exempt them from the physical effort, the hours of "Physical education". For example: only in the pre-university institutions of the Republic of Moldova 15-20\% of the students are released from these hours, this index being constantly increasing: if in 2003 in Chisinau municipality were attested 12 thousand people who did not attend physical education lessons , then in 2004 - already 14 thousand [2], the numbers constantly increasing.

In the Republic of Moldova over $70 \%$ of the students of the secondary school classes do not practice sport, and about $10 \%$ of the students attending the school, drop out of physical education lessons.

Absenteeism not only has direct repercussions on the success of the students in this discipline and on their health status, but also reduces the quality and speed of learning of the material taught and in other disciplines. At the same time, high-profile teachers are not deeply concerned with studying the causes of abandonment of physical education lessons by students, whose knowledge could probably 
contribute to elucidating the main reasons for losing their interest in the discipline taught by them, to diminishing the number of unexcused absences [3].

The authors note not only the poor interest of students in physical education, but also the disinterested attendance of school sports sections. Most of the students present in the gym do not claim to achieve sports performance and participation in competitions, but more advocate for interesting spending of free time, being particularly concerned about the physical appearance of the body [4].

If we refer to the situation in this field in Romania, then we notice that it does not differ fundamentally from that of our country. Thus, about $1 / 2$ of the students in this neighbouring country are exempt from physical education hours, $40 \%$ of them do not practice any sporting activity, and sports only practice $14 \%$ $[5,6]$. The common problems are: the loss of students' interest in physical activity and sports, the lack of motivation to attend classes in the discipline "Physical education", passivity and non-involvement in their performance, the orientation to watch the matches on television.

Motivating students to attend physical education lessons can be viewed as a first step in increasing the efficiency of physical education lessons. In this context Радченко B.H. [7] mentions "... It is important to attract the students to come to the gym and make them work". Motivated physical activity is one of the most important factors to renew the content of the discipline of education, but to educate it is necessary a consistent and responsible attitude of the people who form the partnership teacher-student [8].
The above points out that for the implementation of appropriate methods of training the students in the secondary school, corresponding to their age but also to their interest, it is necessary to know in advance their motivation for attending classes in the discipline "Physical education" at the beginning of the school year. This will allow us to follow the annual dynamics of changing their attitude towards lessons, to have additional evidence regarding the efficiency of the methods used in physical education lessons not only in terms of physiological changes and the level of motor training of students, but also through the terms of the change of attitude towards the discipline "Physical education".

The purpose of the research is to analyze the opinions of 14-15 year-old students regarding the motivation of attending physical education lessons.

Organization of the research: the research was carried out in the $\mathrm{TH}$ "M. Sadoveanu "and $\mathrm{TH}^{\text {" }}$ Pro-success "from Chisinau municipality on a quota of adolescents $(n=70)$ aged $14-15$ years old in the dynamics of the 2015-2016 school year.

To assess the motivation of the students was used the Investigation of the motivation study [9] regarding the attendance of physical education lessons, consisting of 9 questions. Each question asked to choose from the three answer variants, the only one, and this one was appreciated with a certain score. After the sum of the accumulated points, the motivation of the students for attending the physical education lessons was assessed as follows: 2530 points - very high motivation; 20-24 points good motivation; $15-19$ points - positive motivation; $10-14$ points - poor motivation; below 10 points - school inadequacy (Table 1). 
Table 1. Assessment of the motivation level of the students depending on the accumulated score

\begin{tabular}{|c|c|c|l|}
\hline $\begin{array}{c}\text { Nr. } \\
\text { crit. }\end{array}$ & Level & Points & \multicolumn{1}{|c|}{ Motivation } \\
\hline 1 & I & $25-30$ & $\begin{array}{l}\text { Refl Reflects a very high motivation, and the students who } \\
\text { demonstrate such a level are characterized by constant diligence } \\
\text { and the desire to fulfil correctly all the teacher's instructions. } \\
\text { They suffer a lot if they are appreciated with low grades. }\end{array}$ \\
\hline 2 & II & $20-24$ & $\begin{array}{l}\text { Reflects a good motivation, being specific, in particular, to } \\
\text { students who successfully meet the school requirements. But, } \\
\text { compared to the first level students, they do not respect the } \\
\text { entire teacher's instructions, they are freer in making decisions. } \\
\text { This level of motivation is considered a medium one, which is a } \\
\text { common norm. }\end{array}$ \\
\hline 3 & III It & $\begin{array}{l}\text { Characterizes a positive attitude of the students towards the } \\
\text { physical education lessons, but especially with regard to the } \\
\text { motor activities of the second half of the day, such as the } \\
\text { attendance of the sports sections, during which they can } \\
\text { demonstrate not only their physical qualities, but also their way } \\
\text { of "packing" on this occasion - sports suit, sneakers, other } \\
\text { personal attributes. }\end{array}$ \\
\hline 4 & IV & $10-14$ & $\begin{array}{l}\text { It is specific to students with a low motivation for attending } \\
\text { physical education lessons. They come hard at hours, } \\
\text { demonstrating a high degree of indifference. Usually, they drop } \\
\text { out frequently, and if they stay - then they find other concerns, } \\
\text { they play or attend lessons having their place on the gym bench. }\end{array}$ \\
\hline 5 & V & $\begin{array}{l}\text { It is characteristic of students who do not accept the lessons of } \\
\text { physical education and manifest school inadequacy. These } \\
\text { students face serious training problems, have difficulties in } \\
\text { communicating with their peers and the teacher. They regard } \\
\text { the educational environment as a one-size-fits-all, unfriendly, } \\
\text { which is why they can show aggression and lack of tact, in } \\
\text { violation of school rules, refusing to comply with the teachers } \\
\text { instructions. Some of them may have psychological and } \\
\text { emotional disorders, behavioural deviations. }\end{array}$ \\
\hline 10
\end{tabular}

Figure 1 shows the structure of the quota of students from the 9th form, depending on the level of their motivation regarding attending physical education classes. 


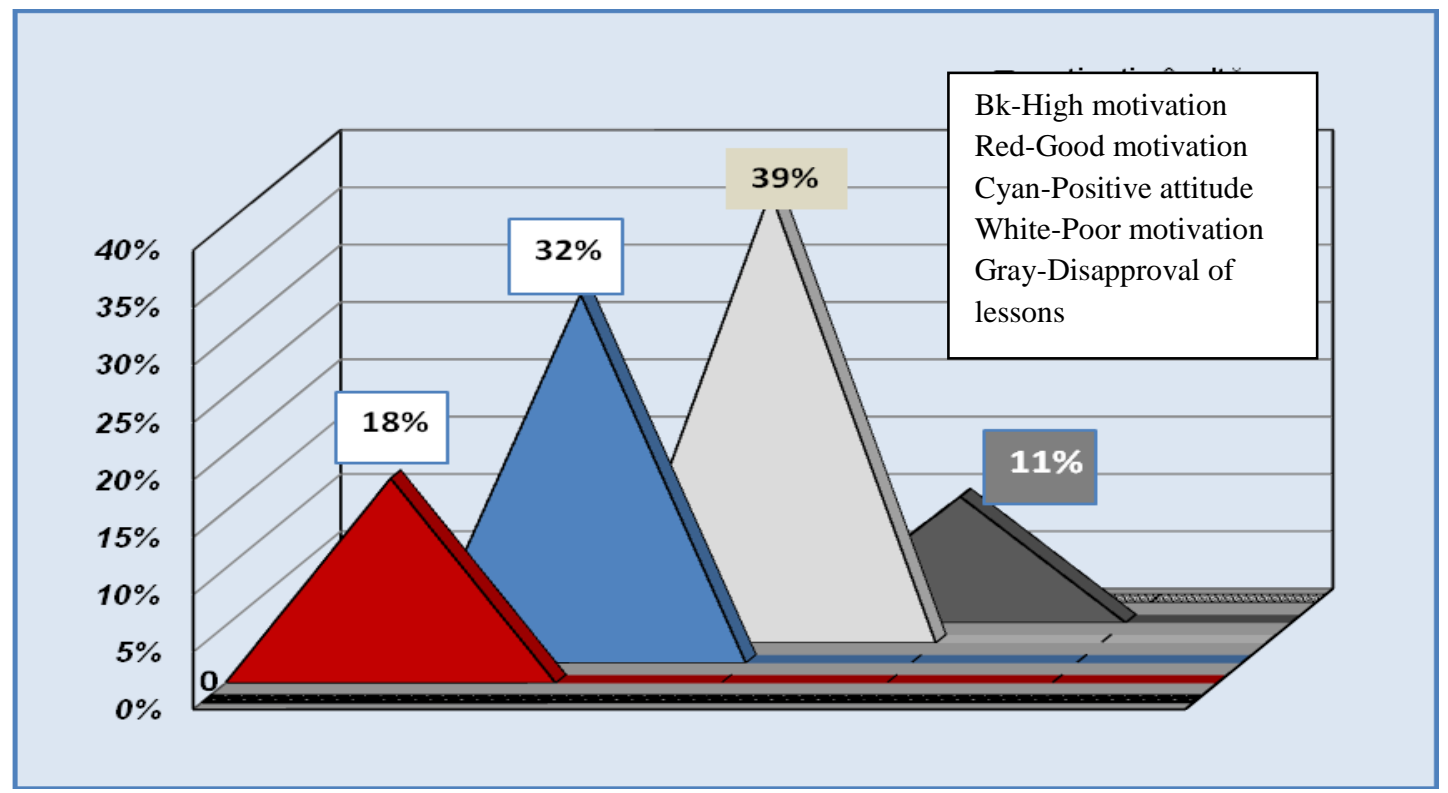

Fig. 1. Structure of the quota of adolescents depending on the motivation of attending the physical education lessons, \%

Based on the criteria for assessing the level of motivation of the students to attend the physical education lessons, it is observed that within the investigated quota (Figure 1) no persons were found with high motivation, most of them having a low motivation, their share constituting 39\%. They are followed by people with a positive motivation, which represents $32 \%$ of the respondents and those with good motivation, their share being $18 \%$. At the same time, it was established that $11 \%$ of them disapprove physical education lessons. So, at the beginning of the school year, $1 / 2$ of adolescents have a positive and good motivation when it comes to attending physical education lessons, and all of them show a poor interest in them and even disapprove of their involvement. These results confirm the need for experimental verification and argumentation of attractive methodologies for conducting the respective lessons, which would increase the gratification and motivation of students regarding attending physical education hours, which would lead to an increase in their level of motor training and, and, on this background in improving the functional state of the body.
Table 2 presents the results of the survey of adolescents regarding the motivation of attending physical education lessons in gender dependence.

Analyzing the data from Table 2, it was established that in the structure of the results of the boys' survey the score predominates, which reflects a good motivation $(38,46 \%)$, specifying, in particular, the students who successfully meet the school requirements, as well as the one that denotes a positive attitude for attending physical education lessons $(34,42 \%)$. At the same time, in the structure of the responses of the girls, those appreciated by 1014 points predominate, the share of which constitutes $46,67 \%$. They reflect a low motivation for attending physical education lessons, demonstrating a high degree of indifference to their content. At the same time, the share of girls who completely disapprove physical education hours is three times lower, compared to boys, constituting only 3,33\%. Therefore, in the context of the researches in this paper we can conclude that it would be rational that the methodology of organizing the physical education lessons, to be implemented, should be addressed to a large extent to the girls, who have a poor interest in them. 
Table 2. Distribution of the responses of girls and boys depending on the score accumulated during the survey, \%

\begin{tabular}{|c|c|c|c|c|}
\hline \multirow{2}{*}{$\begin{array}{c}\text { Nr. } \\
\text { ct. }\end{array}$} & \multirow{2}{*}{ Level } & \multirow{2}{*}{ Points } & \multicolumn{2}{|c|}{$\begin{array}{c}\text { Structure of the answers depending on the accumulated } \\
\text { score }\end{array}$} \\
\cline { 4 - 5 } & & & Boys, \% & Girls, \% \\
\hline 1 & I & $25-30$ & - & - \\
\hline 2 & II & $20-24$ & 15,38 & 23,33 \\
\hline 3 & III & $15-19$ & 38,46 & 26,66 \\
\hline 4 & IV & $10-14$ & 34,62 & 46,67 \\
\hline 5 & V & $<10$ & 11,54 & 3,33 \\
\hline
\end{tabular}

Table 3 presents the structure of the survey, considering their motivation regarding adolescents' answers to the questions in the attending physical education lessons.

Table 3. Distribution of the response variants of adolescents to the survey questions

\begin{tabular}{|c|c|c|c|c|}
\hline No. & Question & Answer variants & $\begin{array}{c}\begin{array}{c}\text { Number of } \\
\text { people }\end{array} \\
\end{array}$ & $\%$ \\
\hline \multirow{3}{*}{1} & \multirow{3}{*}{$\begin{array}{c}\text { Do you like physical education } \\
\text { lesson? }\end{array}$} & yes & 37 & 61,67 \\
\hline & & not too much & 20 & 33,33 \\
\hline & & not & 3 & 5,00 \\
\hline \multirow{3}{*}{2} & \multirow{3}{*}{$\begin{array}{l}\text { If the first lesson is physical } \\
\text { education, are you happy to go to } \\
\text { school? }\end{array}$} & I'm glad & 27 & 45,00 \\
\hline & & happens differently & 27 & 45,00 \\
\hline & & more often not & 6 & 10,00 \\
\hline \multirow{3}{*}{3} & \multirow{3}{*}{$\begin{array}{l}\text { Are you happy when the physical } \\
\text { education lesson is cancelled? }\end{array}$} & no & 19 & 31,67 \\
\hline & & happens differently & 24 & 40,00 \\
\hline & & yes & 17 & 28,33 \\
\hline \multirow{3}{*}{4} & \multirow{3}{*}{$\begin{array}{l}\text { Do you often talk to parents about } \\
\text { physical education hours? }\end{array}$} & frequently & 18 & 30,00 \\
\hline & & rarely & 20 & 30,33 \\
\hline & & do not speak & 22 & 36,67 \\
\hline \multirow{3}{*}{5} & \multirow{3}{*}{$\begin{array}{l}\text { Would you like another physical } \\
\text { education teacher? }\end{array}$} & no & 34 & 56,67 \\
\hline & & I don't care & 16 & 26,67 \\
\hline & & I would like & 10 & 16,67 \\
\hline \multirow{3}{*}{6} & \multirow{3}{*}{$\begin{array}{l}\text { Do you have many friends in the } \\
\text { class? }\end{array}$} & many & 43 & 71,67 \\
\hline & & few & 16,16 & 26,67 \\
\hline & & I have no friends & 1 & 1,67 \\
\hline \multirow{3}{*}{7} & \multirow{3}{*}{ Do you like classmates? } & Yes & 40 & 66,67 \\
\hline & & not too much & 18 & 30,00 \\
\hline & & No & 2 & 3,30 \\
\hline \multirow{3}{*}{8} & \multirow{3}{*}{$\begin{array}{l}\text { Can you say that you attend } \\
\text { physical education lessons formal, } \\
\text { only to avoid absences and } \\
\text { diminish the general success, so as } \\
\text { not to sadden the parents? }\end{array}$} & no, with certainty & 32 & 53,34 \\
\hline & & sometimes & 23 & 38,33 \\
\hline & & Yes & 5 & 8,33 \\
\hline \multirow{3}{*}{9} & \multirow{3}{*}{$\begin{array}{l}\text { Do you respect your physical } \\
\text { education teacher? }\end{array}$} & Yes & 44 & 73,33 \\
\hline & & not too much & 10 & 16,67 \\
\hline & & No & 6 & 10 \\
\hline
\end{tabular}


At the question "Do you like physical education lesson?" The share of students who gave an affirmative answer constituted $61.67 \%$ (Figure 3 ). Thus, $58.83 \%$ of boys and $65.38 \%$ of girls answered, these figures being below the results of the specialized bibliography [10]. At the same time, over $1 / 3(38.33 \%)$ of the respondents mentioned the variants "no" and "not too", this share being, in our opinion, quite high.

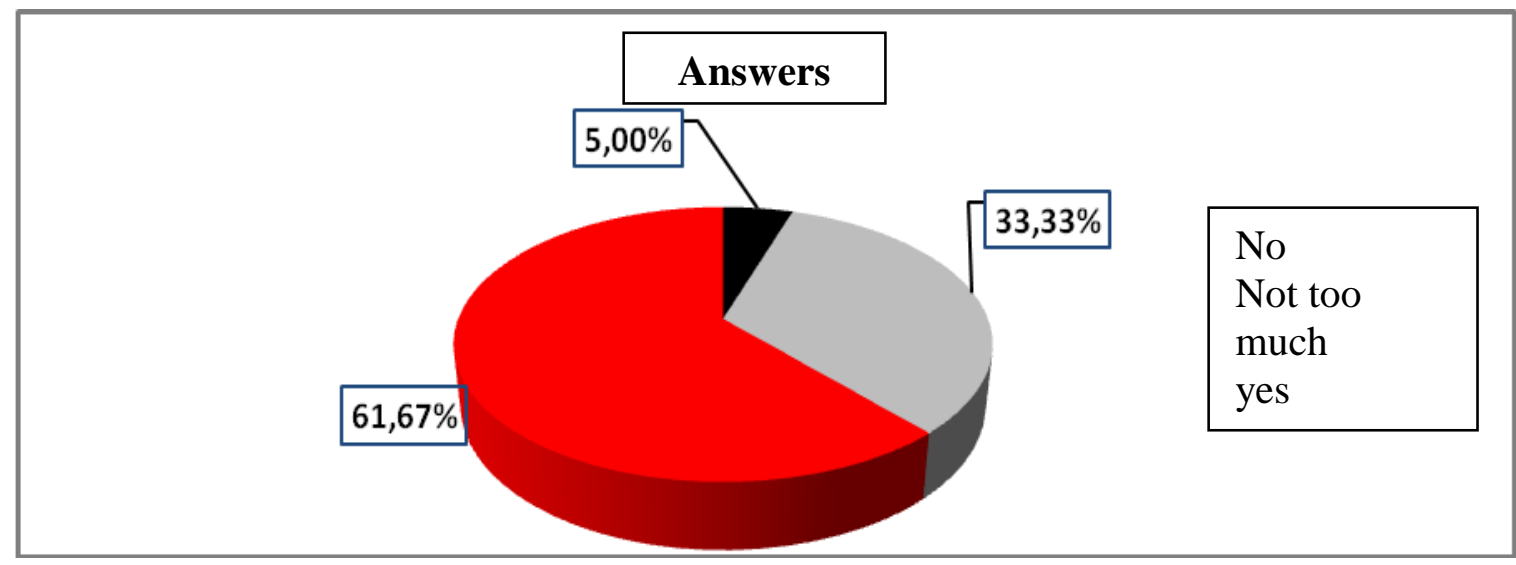

Fig. 3. Structure of adolescents' answers to the question "Do you like physical education?", \%

To the question "If the first lesson is the one of physical education, do you go happy to the lessons?", over $55 \%$ of the students offered the answers "it happens differently" and "no", which reflects an unsatisfactory attitude towards this discipline. In the "no" variant, the boys' response share was higher $(11.76 \%)$, than that of girls $(7.69 \%)$. About $1 / 3$ of the respondents $(31.67 \%)$ are not happy with the cancellation of the physical education lessons, while $28.33 \%$ of them enjoy this situation, the share of the respective boys being higher $(29.4 \%)$, that of girls $(26.92 \%)$.

To the question "Do you want another physical education teacher?" The adolescents' answers were structured as follows (Figure 4): "no" - 56.67\%, "I am indifferent" -26.67\%, " I would like it"- $16.67 \%$. Thus, about $43 \%$ of the students are not quite attached to the teacher, accepting rather easily his replacement with another teacher.

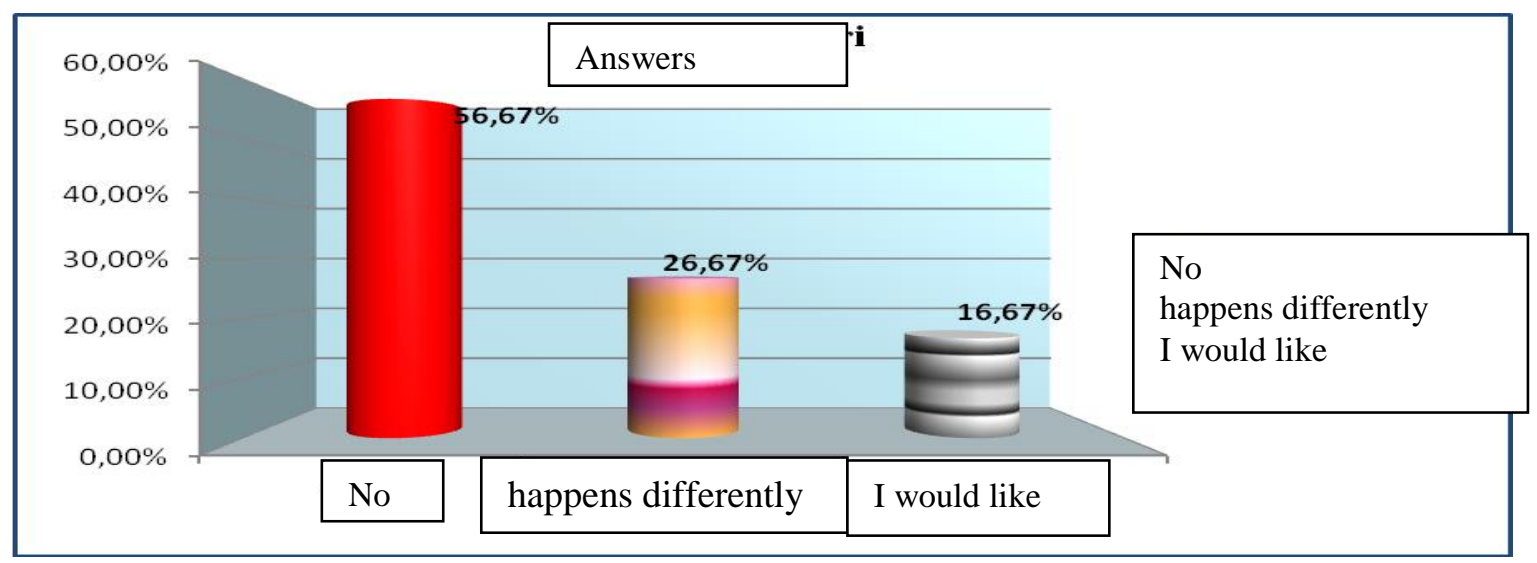

Fig. 4. The structure of the adolescents' answers to the question "Do you want another physical education teacher?", \% 
Given that the motivation for attending classes is largely determined by the student's attitude towards the teacher, it can be concluded from the data obtained that there are certain reservations regarding the establishment of true student-teacher partnership relationships in the teaching of the "Physical education" discipline, which will be useful to consider when implementing the experimental methodology for conducting physical education lessons.

To the question "Can you say that you attend physical education lessons only to avoid absences and diminish the general success, not to sadden the parents?" The answers were distributed as follows: the share of students who answered "no, with certainty" constitutes 53.34\%, "sometimes" - 38.33\%, and "yes" $8.33 \%$. But the attitude of boys and girls in this chapter is different. Thus, only $47.06 \%$ of boys responded promptly "no, with certainty", and the share of girls with such narrow responses of $61.54 \%$, which indicates a more responsible attitude of girls towards attending physical education lessons.

To the question "Do you respect your physical education teacher?", the teenagers offered the following answers: "yes" - 73.73\%, "not too" - 16.67\%, "no" - 10\%. But from the comparative analysis of their structure, for girls and boys, it was established (Figure 5) that the vast majority of the girls surveyed respect their teacher, their share constituting $80.77 \%$, their boys' share being only $67.65 \%$. The share of boys and girls who offered "not too" questionable answers to this question is different, accounting for $14.7 \%$ and $19.23 \%$ respectively. At the same time, we would like to mention that no girl specified in her answer the lack of respect for the teacher, which denotes a certain level of education and culture.

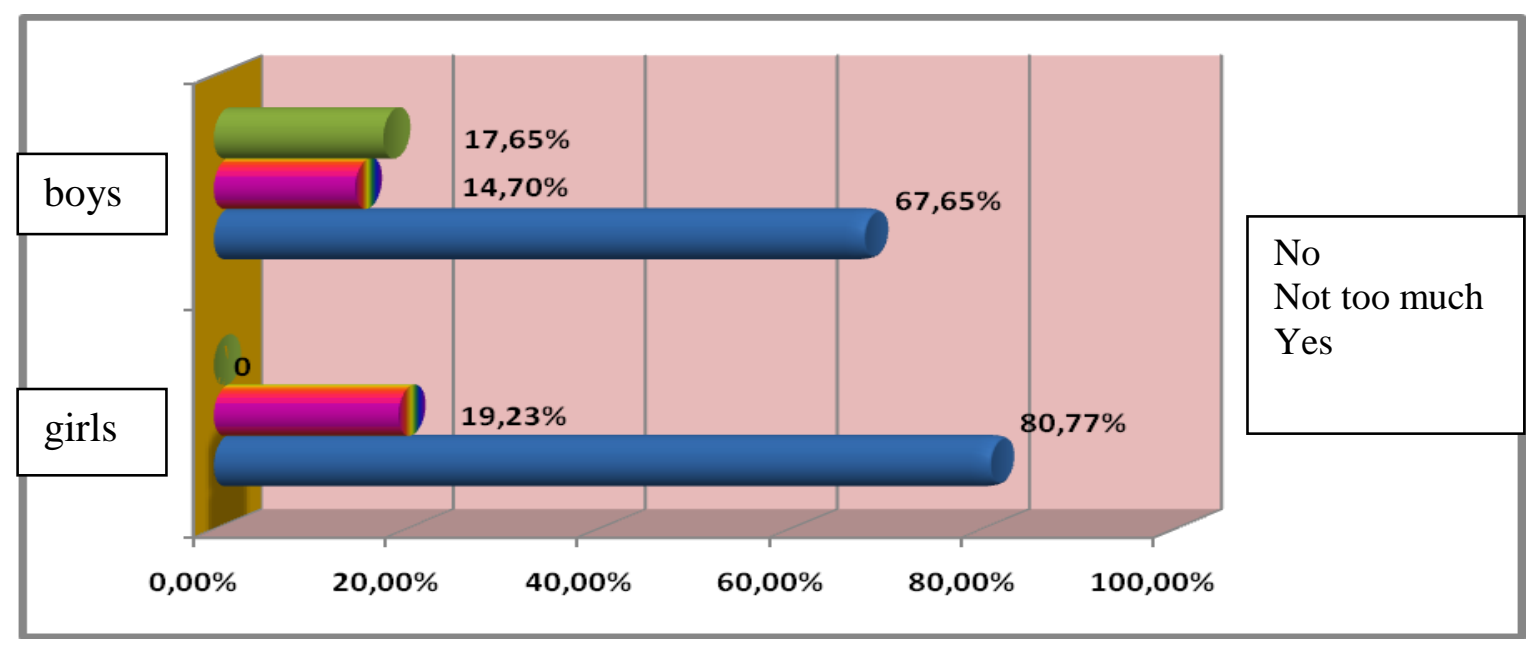

Fig. 5. Comparative presentation of the structure of boys and girls answers to the question "Do you respect your physical education teacher?", \%

Thus, by surveying adolescents at the beginning of the school year, it was established that among them there are no strong motivation to attend physical education lessons. Among boys, those with a positive and good motivation predominate, compared to attending the respective discipline, at the same time most girls have a low level of motivation in this regard. Detailed analysis of the structure of adolescents' responses to the survey highlighted the main factors that influence the motivation of girls and boys, among which are listed: the attitude already created towards this discipline during the years of studies, the relations of friendship with 
colleagues, teacher-student relations, respect for the teacher, etc.

These results confirm, in part, the data from the specialized bibliography regarding the poor motivation of adolescents in relation to physical education. At the same time, they can serve as the basis for the implementation of attractive methods of organizing physical education lessons, which can provide positive emotions and the possibility of personal affirmation of the students.

\section{Conclusions:}

1. The increase of the motivation level of the 14-15 year-old students for attending the lessons of physical education, can be realized only by a good motivator, in this case the teacher of physical education and a good relation between them. A good teacher-student relationship determines the motivation of the latter to get actively and successfully involved in the proposed activities and tasks. Without motivation, of any kind, a person does not engage in an action.

2. The opinion survey of 14-15 year-old students, carried out by us, revealed their real motivation for attending physical education lessons. Thus, $39 \%$ of them have a poor motivation, and $11 \%$ disapprove of these hours, which denote the need to increase the attractiveness of the discipline "Physical education" by efficient methods and means.

\section{References:}

1. Cristea D., Oros S., Lucaciu Gh. ş.a. Study on the attractiveness of physical education lessons for high school students. http://www.fefsoradea.ro/Fascicula_Educatie_Fizica_si_Sport/2011/Cristea.pdf 06.04.2016).

(accessed

2. The concept of the development of physical culture and sport in the Republic of Moldova http://www.referat.ro/referate/Conceptia_dezvoltarii_culturii_fizice_si_sportului_in_Republica_Mo ldova_6e1b html (accessed on 02.07. 2015).

3. Iziumov N. (2010). Complex assessment of the health status of adolescents aged 15-18 from the Republic of Moldova. $\mathrm{PhD}$ thesis in medicine. Chisinau. $175 \mathrm{p}$.

4. Михашенко А.А. (2014). Моральная проблема как один из острых вопросов физической культуры и спорта. В: Актуальные проблемы развития физической культуры и спорта в Восточной Сибири. Материалы областной научно-практической конференции студентов, аспирантов и молодых ученых. Иркутск, с. 32-35.

5. Beius F. Driving motor skills through the physical education lesson. www.cdep.ro/proiecte/2006/700/80/3/em783.pdf (accessed on 10.07.2014).

6. Half of the students are exempt from sports classes. Obesity is an inevitable consequence. http://www.realitatea.net/jumatate-dintre-elevi-au-scutire-la-orele-de-sport-obezitatea-o-consecintainevitabila_1722361.html\#ixzz3gd7SRcaI (accessed on 16.07.2016).

7. Радченко В.Н. (2004). Оптимизация физического воспитания как ведущчий фактор формирования здорового образа жизни и повышения мотиващии к занятиям физической культурой. Москва: Физкультура и спорт. 53 с.

8. Моченов В. П. (2014). Объективные трудности построения общей теории в сфере физической культуры и спорта. В: Материалы Всероссийской научно-практической конференции «Физическая культура и спорт в системе образования России: инновации и перспективы развития». Санкт-Петербург, 212 с.

9. Carter P. (2007). Cartea completă a testelor de inteligență. București: Editura Meteor Press. 277p.

10. Молчанова Ю.С. (2007). Формирование потребностей $\kappa$ занятиям физической культурой у школьников 14-15 лет. Дисс. кандидата педагогических наук. Белгород. 153 с. 